\title{
Stalk Rot Fungi Affect Leaf Greenness (SPAD) of Grain Sorghum in a Genotype- and Growth-Stage-Specific Manner
}

\author{
Y. M. A. Y. Bandara, Department of Plant Pathology, D. K. Weerasooriya and T. T. Tesso, Department of Agronomy, and C. R. Little, \\ Department of Plant Pathology, Kansas State University, Manhattan 66506
}

\begin{abstract}
Bandara, Y. M. A. Y., Weerasooriya, D. K., Tesso, T. T., and Little, C. R. 2016. Stalk rot fungi affect leaf greenness (SPAD) of grain sorghum in a genotype- and growth-stage-specific manner. Plant Dis. 100:2062-2068.

Stalk rots are among the most prevalent and destructive sorghum diseases worldwide. Although experimental evidence is limited, delayed postflowering senescence due to the staygreen trait is accepted as a physiological means of stalk rot resistance. Staygreen has been shown to be correlated with chlorophyll content (as measured by a soil and plant analytical development [SPAD] meter). Field experiments were conducted to test the effects of Fusarium stalk rot and charcoal rot on SPAD readings at three developmental stages, to test whether staygreen genotypes are more resilient to stalk-rot-mediated chlorophyll degradation, and to examine the relationships between SPAD and stalk rot resistance and tolerance when plants were inoculated with causal organisms. Staygreen and nonstaygreen lines (two) and hybrids (two) established in the field were inoculated with Fusarium thapsinum, F. proliferatum, F. andiyazi, and Macrophomina

phaseolina at 14 days after flowering. SPAD readings were obtained at soft-dough, hard-dough, and physiological maturity. Most pathogens significantly reduced the SPAD of the genotypes over the mock-inoculated control at three developmental stages. The stalk-rot-resistant and staygreen check line, SC599, showed a remarkable feature of negative senescence from soft dough to physiological maturity under disease pressure. Disease severity was significantly and negatively correlated with SPAD at all developmental stages, revealing the potential impact of the staygreen trait on stalk rot resistance. The difference between control and pathogentreated total seed weight per panicle (i.e., tolerance) was significantly and positively correlated with the difference between control and pathogentreated SPAD at physiological maturity, demonstrating the ability of staygreen trait to enhance stalk rot tolerance under disease pressure.
\end{abstract}

Stalk rots are among the most prevalent and destructive diseases of sorghum (Sorghum bicolor L. Moench) worldwide (Tesso et al. 2010). There are two stalk rot diseases of sorghum: Fusarium stalk rot, also called "soft rot," caused by Fusarium spp., and charcoal rot, caused by Macrophomina phaseolina (Tassi) Goid. (Tarr 1962). Degradation of pith tissue at or near the base of the stalk leads to pith cell death and is the primary symptom of both diseases (Tesso et al. 2012). Infected plants often have damaged vascular and cortical tissues in both the root and stalk systems that reduce nutrient and water absorption and translocation (Hundekar and Anahosur 1994). Under extreme conditions, stalk rot diseases can cause plant lodging and significant yield loss (Tesso et al. 2004). Prolonged postflowering drought stress, heat stress, and unbalanced mineral nutrition aggravate stalk rot diseases (Dodd 1980; Seetharama et al. 1987; Tesso et al. 2004). Jardine and Leslie (1992) have shown that the average yield loss caused by stalk rots in Kansas is about $4 \%$ while the loss at specific locations can reach as much as $50 \%$. Stalk-rot-induced lodging of up to $60 \%$ is common among high-yielding hybrids in Kansas, and the incidence can be even higher under stressful conditions (Tesso et al. 2004). Tesso et al. (2004) estimated that the annual economic loss associated with this disease in Kansas surpasses \$15 million per year.

Delayed senescence (or "staygreen") in sorghum is widely accepted as a valuable trait because it improves the ability of a genotype to adapt to postflowering drought stress, particularly when the crop depends on residual soil moisture for grain development and maturity (Rosenow et al. 1977). Greater green-leaf-area duration during grain filling is a result of different combinations of three factors: green leaf

\section{Corresponding author: C. R. Little; E-mail: crlittle@ksu.edu}

This article is contribution number 16-317-J from the Kansas Agricultural Experiment Station, Manhattan.

Accepted for publication 6 June 2016.

http://dx.doi.org/10.1094/PDIS-02-16-0171-RE

(C) 2016 The American Phytopathological Society area at flowering, senescence onset time, and rate of senescence (Borrell et al. 2000a; van Oosterom et al. 1996). Furthermore, this trait has a slight, if any, yield penalty when plants are grown in environments where water is not a limiting factor (Borrell et al. 2000b). Xu et al. (2000) have shown that the soil and plant analytical development (SPAD) value (measured by a SPAD meter) is significantly and linearly correlated with total leaf chlorophyll $\left(R^{2}=-0.91\right)$ and with visual staygreen ratings $\left(R^{2}=-0.82\right)$. This instrument determines the relative quantity of chlorophyll present in leaf tissue by measuring red and infrared leaf transmittance (at wavelengths of 650 and $940 \mathrm{~nm}$, respectively) (Yamamoto et al. 2002). Transmittance values are used by the device to derive a relative SPAD meter value that is proportional to chlorophyll content in the sample (Uddling et al. 2007). Therefore, SPAD readings measured from the early reproductive to physiological maturity stages can be used to assess the staygreen capacity of grain sorghum genotypes. Xu et al. (2000) used SPAD values at physiological maturity as the direct indicator of the staygreen trait.

Staygreen has been reported to be associated with reduced lodging (Mughogho and Pande 1984) and lower susceptibility to charcoal rot (Mughogho and Pande 1984; Tenkouano et al. 1993). Moreover, as mentioned above, staygreen in sorghum is known to improve the ability to adapt to postflowering drought stress. By the end of the 21st century, global surface temperatures are predicted to increase by 1.4 to $5.8^{\circ} \mathrm{C}$ (IPCC 2007). Drought is the most important abiotic stressor that directly affects yield. The increased frequency of prolonged water stress events is both an indicator and a predicted outcome of future climate change (Araus et al. 2002; Meehl et al. 2007). According to Meehl et al. (2007), an increased frequency of drought incidents is an important feature of the forecasted climatic changes along with short episodes of high temperature.

Cool and moist weather conditions at physiological maturity that are preceded by drought and heat during grain formation tend to exacerbate Fusarium stalk rot severity while prolonged exposure to drought and high-temperature stress throughout host development increases charcoal rot incidence (Tesso et al. 2012). Under insufficient moisture, sorghum is subject to drought-associated root and stalk rots that could lead to lodging, as well as loss of stover, grain 
quality, and productivity (Borrell et al. 2000b). Lodging poses an additional challenge under mechanized harvesting and contributes to reduced harvestable yields and quality. M. phaseolina is considered a high-temperature pathogen, with the severity of the disease increasing as air and soil temperatures rise from 28 to $35^{\circ} \mathrm{C}$ and when soil moisture becomes limiting (Gray et al. 1991; Smith and Wyllie 1999). Therefore, under predicted future climatic changes, tremendous yield losses due to intensified charcoal and Fusarium stalk rot incidence around the world could be expected in many economically important crops, including sorghum. In that context, staygreen is an increasingly important trait to be pursued and incorporated in future breeding efforts to face these challenges.

Although staygreen is common among certain genotypes of many economically important crop species (Thomas and Smart 1993) that are prone to stalk and root rot diseases, experimental evidence for the degree of association or correlation between staygreen and charcoal rot and Fusarium stalk rot resistance are currently lacking. Further, the effect of stalk rot pathogens on leaf chlorophyll content and the relationship between staygreen and stalk rot tolerance are unknown. Therefore, the objectives of this study were to (i) determine the effects of multiple stalk rot pathogens on SPAD readings at three developmental stages (soft dough, hard dough, and physiological maturity), (ii) test whether staygreen genotypes are more resilient to stalk-rot-mediated chlorophyll degradation, and (iii) investigate the degree of correlation between staygreen and stalk rot resistance and tolerance when plants were inoculated with Fusarium thapsinum, F. andiyazi, F. proliferatum, and M. phaseolina by using grain sorghum as a model system.

\section{Materials and Methods}

Sorghum genotypes and fungal pathogens. Four sorghum genotypes, including two hybrids and two inbred lines, were used for this study. The two hybrids used were DKS37-07 (Monsanto; staygreen and charcoal rot resistant) and 84G62 (Dupont Pioneer; charcoal rot tolerant). These are commonly grown hybrids in the state of Kansas. SC599R (Fusarium stalk rot and charcoal stalk rot resistant, staygreen) and BTx3042 (Fusarium stalk rot and charcoal rot susceptible, nonstaygreen) were the two breeding lines used. The M. phaseolina isolate (r144) utilized in this study was provided by Dr. Gary Odvody, Texas A\&M AgriLife Research and Extension, Corpus Christi. The three Fusarium spp. used in this study ( $F$. thapsinum, $F$. proliferatum, and $F$. andiyazi) were obtained from the culture collection of the Row Crops Pathology Lab at the Department of Plant Pathology, Kansas State University. For information on cultural and molecular identification of the isolates used, please refer to Bandara et al. (2015).

Establishment and maintenance of plants in the field. Two field experiments were conducted during the 2013 and 2014 main seasons at the Kansas State University agronomy research farms near Manhat$\tan , \mathrm{KS}\left(39.22^{\circ} \mathrm{N}, 96.60^{\circ} \mathrm{W}\right)$ and Ashland, $\mathrm{KS}\left(39.13^{\circ} \mathrm{N}, 96.62^{\circ} \mathrm{W}\right)$, respectively (hereafter referred to as the two environments). Field preparation, planting, and crop maintenance were conducted according to standard procedures for sorghum. Seed treated with ethyl mercaptan (Captan; $2 \mathrm{ml} \mathrm{kg}{ }^{-1}$ seed) were planted in rows of $5 \mathrm{~m}$ in length by $0.75 \mathrm{~m}$ in width. Eighty seeds were planted per plot that resulted in a plant stand of 60 to 65 plants. Seedlings were not thinned. A fourby-five-by-three factorial treatment structure was deployed to investigate SPAD response, where factors one, two, and three consisted of sorghum genotype, inoculation treatment, and developmental stages, respectively, at which SPAD measurements were acquired. For disease severity (lesion length) and yield measurements (total seed weight [TSW] per panicle and 100-seed weight [HSW]), a treatment structure of four-by-five factorial was used, excluding the developmental stage factor (see below). Both experiments were arranged in a split-plot design with randomized complete blocks. Genotypes were assigned to the whole-plot unit, whereas pathogens with control treatments were assigned to the subplot unit. Each experiment was replicated three times (i.e., three blocks). At 4 weeks after planting, three plants in each of the five subplots were tagged using five different-colored tapes (three plants of each color) to demarcate the pathogen or control treatment they would receive at 2 weeks after flowering. There were three subsample plants (observational unit) at the level of each treatment.
Inoculum preparation, artificial inoculation, SPAD, disease severity, and yield measurements. The protocol described by Bandara et al. (2015) was used to prepare Fusarium spp. and M. phaseolina inocula. Briefly, liquid cultures (potato dextrose broth) were grown at $30^{\circ} \mathrm{C}$ for 5 days to obtain Fusarium spp. conidia and M. phaseolina mycelia. Filtrates containing Fusarium spp. conidia and M. phaseolina hyphal fragments were centrifuged and diluted with sterile $10 \mathrm{mM}$ phosphatebuffered saline (PBS; $2.17 \mathrm{~g}$ of $\mathrm{NaCl}, 8.71 \mathrm{~g}$ of $\mathrm{Na}_{2} \mathrm{HPO}_{4} \cdot 7 \mathrm{H}_{2} \mathrm{O}$, and $0.26 \mathrm{~g}$ of $\mathrm{KH}_{2} \mathrm{PO}_{4}$ dissolved in 1 liter of sterile-distilled $\mathrm{H}_{2} \mathrm{O}$; $\mathrm{pH}$ 7.2). All inoculum preparation steps were performed under aseptic conditions. Inoculations were performed at 14 days after anthesis. Plants were inoculated using a 10-ml, 20-gauge, 3.8-cm needle, sterile surgical syringe by injecting $0.1 \mathrm{ml}$ of inoculum with a concentration of $2 \times 10^{6}$ conidia (for the three Fusarium spp.) or mycelial fragments (M. phaseolina) per milliliter into the basal node of the stalk. PBS was used as the mock-inoculated control treatment.

Chlorophyll content of the flag leaf of each inoculated and control plant was measured using a SPAD meter (Minolta SPAD 502 chlorophyll meter; Spectrum Technologies, Inc.). All SPAD measurements were acquired at the base, center, and the tip of the leaf lamina and averaged. SPAD was measured at the soft dough, hard dough, and physiological maturity stages at 7, 19, and 31 days after inoculation, respectively. Plants were harvested at 42 days after inoculation. The stalks of harvested plants were longitudinally split using a knife and the length (in centimeters) of the pigmented lesion that occurs due to infection of stalk rot pathogens was measured using a tape. Panicles were separated from plants and dried for 10 days at $40^{\circ} \mathrm{C}$ and threshed to measure TSW per panicle using a weighing scale. HSW was computed by dividing the TSW per panicle by the total number of seed per panicle. An automated seed counter was used to count the seed.

Statistical analysis. SAS software, version 9.2 (SAS Institute 2008) was used for all data analyses. Data were subjected to analysis of variance (ANOVA) using the PROC GLIMMIX procedure. The KenwardRoger option was used to compute the denominator degrees of freedom in $F$ tests. Environment, genotype, inoculation treatment, and developmental stage were considered as fixed factors for SPAD measurements. Environment, genotype, and pathogen treatment were considered as fixed factors for yield (TSW per panicle and HSW) and disease severity (lesion length) traits. Block was regarded as a random factor nested within environment. Because SPAD measurements at the three maturity stages were repeated measures and were correlated with each other, there was a covariance structure to the data at the level of developmental stage. Hence, a time series analysis was conducted by modeling data for the most suitable variance-covariance structure. The data were modeled with first-order antedependence covariance structure. Bayesian information criterion was used as the basis for model selection. In the case of the other response variables (i.e., TSW per panicle, HSW, and lesion length), the model assumptions were tested using Studentized residual plots (for identical and independent distribution of residuals) and Q-Q plots (for normality of residuals). Whenever residuals were not homogeneously distributed, appropriate heterogeneous variance models were fitted to meet the model assumptions. Means separations were carried out using the PROC GLMMIX procedure of SAS. Main effects of factors were determined with adjustments for multiple comparisons by using the Tukey-Kramer test. Simple effects of factors were determined using the Bonferroni adjustment when higher-order interactions among factors are statistically significant for the trait concerned. Only relevant pairwise comparisons were considered for determining the critical comparison-wise error rate $\left(\alpha_{\mathrm{CER}}\right)$ and subsequently compared against unadjusted $P$ values resulting from Bonferroni correction to test the significance of mean treatment differences. Pearson correlation coefficients and significance levels among measured traits were computed using the PROC CORR procedure of SAS.

\section{Results}

ANOVA revealed a statistically nonsignificant four-way interaction effect between environment, genotype, treatment, and developmental stage for SPAD at the 5\% significance level (Table 1). The threeway interactions between genotype, pathogen, and developmental 
stage and environment, genotype, and developmental stage were significant. Except for the interactions of pathogen with environment and developmental stage, all other two-way interactions were significant. ANOVA conducted for the computed values of mean SPAD difference (SPAD at physiological maturity $\left[\mathrm{SPAD}_{p m}\right]-\mathrm{SPAD}$ at soft dough stage $\left[\mathrm{SPAD}_{s d}\right]$ ) revealed significant genotype main effects (Table 1). The genotype-pathogen interaction was significant for TSW per panicle, whereas significant main effects of all three factors were evident for HSW. The environment-genotype-pathogen interaction was significant for lesion length.

$F$. andiyazi, F. proliferatum, F. thapsinum, and M. phaseolina significantly reduced the SPAD of $84 \mathrm{G} 62$ at hard dough $(P=0.005)$ and physiological maturity $(P<0.0001)$ over the respective controls, while only $F$. thapsinum and $M$. phaseolina significantly reduced the SPAD at soft dough stage $(P=0.0024$ and $P<0.0001$, respectively) compared with the control (Table 2). Although no significant SPAD differences among the pathogens were observed for 84G62 at hard dough and physiological maturity, F. thapsinum and M. phaseolina resulted in significantly lower SPAD readings in comparison with $F$. andiyazi and $F$. proliferatum at the soft dough stage. All four pathogens significantly reduced the SPAD of DKS37-07 at soft dough $(F$. andiyazi, $P=0.001$; others, $P<0.0001)$, hard dough $(P<0.0001)$, and physiological maturity $(P<0.0001)$ in comparison with their respective controls. At physiological maturity, M. phaseolina had a significantly greater SPAD reduction $(P<0.001)$ compared

Table 1. $P$ values of $F$ tests from analysis of variance for soil and plant analytical development (SPAD) meter readings measured at soft dough, hard dough, and physiological maturity stages; and total seed weight (TSW) per panicle, 100-seed weight (HSW), and lesion length (LL) as measured with four sorghum genotypes after inoculation with Fusarium thapsinum, $F$. andiyazi, F. proliferatum, and Macrophomina phaseolina $(\alpha=0.05)$

\begin{tabular}{lrrrrr}
\hline & \multicolumn{5}{c}{ Pr $\boldsymbol{P}^{\mathbf{y}}$} \\
\cline { 2 - 6 } Effect & \multicolumn{1}{c}{ SPAD } & $\boldsymbol{\Delta S P A D}^{\mathbf{z}}$ & \multicolumn{1}{c}{ TSW } & HSW & \multicolumn{1}{c}{ LL } \\
\hline Environment (E) & $<0.0001$ & 0.1852 & $<0.0001$ & 0.0002 & 0.3154 \\
Genotype (G) & 0.0001 & $<0.0001$ & $<0.0001$ & $<0.0001$ & 0.0031 \\
E $\times$ G & $<0.0001$ & 0.1282 & $<0.0001$ & $<0.0001$ & $<0.0001$ \\
Treatment (T) & $<0.0001$ & 0.2430 & $<0.0001$ & 0.0002 & $<0.0001$ \\
E $\times$ T & 0.1173 & 0.0692 & 0.9362 & 0.8979 & 0.6096 \\
G $\times$ T & 0.0002 & 0.1006 & 0.0094 & 0.7476 & $<0.0001$ \\
E $\times$ G $\times$ T & 0.1348 & 0.1611 & 0.0948 & 0.1236 & $<0.0001$ \\
Stage (S) & 0.0002 & $\ldots$ & $\ldots$ & $\ldots$ & $\ldots$ \\
E $\times$ S & $<0.0001$ & $\ldots$ & $\ldots$ & $\ldots$ & $\ldots$ \\
G $\times$ S & 0.0461 & $\ldots$ & $\ldots$ & $\ldots$ & $\ldots$ \\
E $\times$ G $\times$ S & 0.0002 & $\ldots$ & $\ldots$ & $\ldots$ & $\ldots$ \\
T $\times$ S & 0.6279 & $\ldots$ & $\ldots$ & $\ldots$ & $\ldots$ \\
E $\times$ T $\times$ S & 0.1517 & $\ldots$ & $\ldots$ & $\ldots$ & $\ldots$ \\
G $\times$ T $\times$ S & 0.0241 & $\ldots$ & $\ldots$ & $\ldots$ & $\ldots$ \\
E $\times$ G $\times$ T $\times$ S & 0.0511 & $\ldots$ & $\ldots$ & $\ldots$ & $\ldots$ \\
\hline
\end{tabular}

y TSW, HSW, and LL were measured at physiological maturity.

${ }^{\mathrm{z}}$ SPAD meter reading difference between physiological maturity and soft dough stages $\left(\mathrm{SPAD}_{p m}-\mathrm{SPAD}_{s d}\right)$. with $F$. andiyazi, although pathogens were not significantly different from each other at soft and hard dough stages. All four pathogens significantly reduced the SPAD of BTx3042 at hard dough stage $(F$. andiyazi, $P=0.006$; others, $P<0.0001)$ compared with the control. At soft dough stage, except for $F$. andiyazi, the other three pathogens significantly reduced SPAD compared with the control $(P<0.0001)$. $F$. proliferatum $(P<0.0006)$ and $M$. phaseolina $(P<0.0001)$ significantly reduced SPAD compared with the control at physiological maturity. All four pathogens significantly decreased the SPAD of SC599 at soft dough $(P<0.0001)$, hard dough $(P<0.0001)$, and physiological maturity (M. phaseolina; $P=0.0015$, others; $P<0.0001)$ compared with the respective controls. Across environments and treatments, SC599 showed a positive SPAD difference $\left(\mathrm{SPAD}_{p m}>\mathrm{SPAD}_{s d}\right)$, while 84G62, BTx3042, and DKS37-07 had negative SPAD differences $\left(\mathrm{SPAD}_{p m}<\mathrm{SPAD}_{s d}\right)$ (Fig. 1). The latter three were significantly different from the former $(P=0.003, P=0.001$, and $P<0.0001$, respectively).

$F$. andiyazi, F. proliferatum, $F$. thapsinum, and $M$. phaseolina significantly reduced the TSW per panicle of $84 \mathrm{G62}(F$. andiyazi, $P<$ 0.005 ; F . proliferatum, $P<0.001$; others, $P<0.0001)$, DKS37-07 $(P<0.0001)$, SC599 $(P<0.0001)$, and BTx3042 $(M$. phaseolina; $P<0.0001$, others; $P<0.001)$ in comparison with their respective controls (Table 3). However, pathogens did not significantly differ among themselves for any of the genotypes. $F$. andiyazi, $F$. proliferatum, $F$. thapsinum, and $M$. phaseolina significantly decreased the HSW compared with the control $(P<0.0001)$ (Fig. 1).

All pathogens significantly increased the lesion lengths of all genotypes in both environments in comparison with the control treatment $(P<0.001$; Table 4$)$. In the 2013 experiment, $F$. thapsinum produced the longest mean lesion length of $11.2 \mathrm{~cm}$ in $84 \mathrm{G} 62$, which was significantly higher than the stalk lesions caused by the other pathogens in this commonly grown hybrid $(P<0.005)$. In 2014, $F$. thapsinum produced a mean lesion length of $7.5 \mathrm{~cm}$ in $84 \mathrm{G} 62$. In both years, $M$. phaseolina produced the shortest lesion lengths in this hybrid. F. thapsinum produced the longest lesion length in DKS3707 in both years, while $M$. phaseolina produced the lowest lesion lengths. For BTx3042, M. phaseolina produced the largest lesion length in both environments and $F$. thapsinum produced the shortest lesion lengths. SC599, in general, showed the shortest lesion length values against tested pathogens in both years. Although all pathogens produced significantly higher lesion lengths compared with the control $(P<0.001)$, the pathogens were not significantly different from each other for the stalk-rot-resistant, staygreen line SC599 (Table 4).

Pearson correlation coefficient analysis revealed significant correlations between SPAD measured at the three developmental stages as well as the mean SPAD across the three developmental stages with TSW per panicle and lesion length in both environments (Table 5). The correlation coefficients $(r)$ between TSW per panicle and SPAD at the soft dough, hard dough, and physiological maturity stages and mean SPAD in 2013 were similar to those in $2014(P<0.0001)$. $P$ values for the correlation coefficients between HSW and the abovementioned SPAD values were much stronger in $2014(P<0.0001)$ compared with those in $2013(P=0.013, P=0.018, P<0.0001$, and $P<0.011$, respectively). Lesion length data in both environments

Table 2. Mean soil and plant analytical development (SPAD) values (in relative SPAD units) of sorghum hybrids and lines at soft dough (SD), hard dough (HD), and physiological maturity (PM) after inoculation with phosphate buffered saline (mock-inoculated control), Fusarium andiyazi, F. proliferatum, F. thapsinum, and Macrophomina phaseolina across the 2013 and 2014 experiments $^{\mathrm{z}}$

\begin{tabular}{|c|c|c|c|c|c|c|c|c|c|c|c|c|}
\hline \multirow[b]{3}{*}{ Treatment } & \multicolumn{6}{|c|}{ Hybrids } & \multicolumn{6}{|c|}{ Lines } \\
\hline & \multicolumn{3}{|c|}{ 84G62 } & \multicolumn{3}{|c|}{ DKS37-07 } & \multicolumn{3}{|c|}{ BTx3042 } & \multicolumn{3}{|c|}{ SC599 } \\
\hline & SD & HD & PM & SD & HD & PM & SD & HD & PM & SD & HD & PM \\
\hline Control & $58.5 \mathrm{a}$ & $59.3 \mathrm{a}$ & $56.8 \mathrm{a}$ & $58.9 \mathrm{a}$ & $58.6 \mathrm{a}$ & $58.9 \mathrm{a}$ & $57.2 \mathrm{a}$ & $57.3 \mathrm{a}$ & $52.1 \mathrm{a}$ & $54.8 \mathrm{a}$ & $55.9 \mathrm{a}$ & $56.5 \mathrm{a}$ \\
\hline F. andiyazi & $54.2 \mathrm{a}$ & $54.6 \mathrm{~b}$ & $50.1 \mathrm{~b}$ & $53.2 \mathrm{~b}$ & $51.9 \mathrm{~b}$ & $50.7 \mathrm{~b}$ & $53.4 \mathrm{ab}$ & $52.7 \mathrm{~b}$ & $51.6 \mathrm{a}$ & $45.2 \mathrm{~b}$ & $45.4 \mathrm{c}$ & $45.1 \mathrm{c}$ \\
\hline F. proliferatum & $54.1 \mathrm{a}$ & $54.2 \mathrm{~b}$ & $50.5 \mathrm{~b}$ & $51.5 \mathrm{~b}$ & $50.4 \mathrm{~b}$ & $47.3 \mathrm{bc}$ & $49.5 \mathrm{bc}$ & $46.6 \mathrm{c}$ & $46.5 \mathrm{~b}$ & $47.6 \mathrm{~b}$ & $49.7 \mathrm{~b}$ & $47.0 \mathrm{bc}$ \\
\hline F. thapsinum & $53.2 \mathrm{~b}$ & $53.9 \mathrm{~b}$ & $51.4 \mathrm{~b}$ & $51.5 \mathrm{~b}$ & $50.8 \mathrm{~b}$ & $48.3 \mathrm{bc}$ & $48.6 \mathrm{c}$ & $49.1 \mathrm{bc}$ & $48.3 \mathrm{ab}$ & $46.5 \mathrm{~b}$ & $48.8 \mathrm{~b}$ & $46.6 \mathrm{bc}$ \\
\hline M. phaseolina & $51.5 \mathrm{~b}$ & $52.8 \mathrm{~b}$ & $48.6 \mathrm{~b}$ & $50.9 \mathrm{~b}$ & $50.1 \mathrm{~b}$ & $45.2 \mathrm{c}$ & $47.7 \mathrm{c}$ & $47.0 \mathrm{c}$ & $45.4 \mathrm{~b}$ & $47.9 \mathrm{~b}$ & $49.1 \mathrm{~b}$ & $48.3 \mathrm{~b}$ \\
\hline
\end{tabular}

${ }^{\mathrm{z}}$ Standard error for each mean is 1.2. Means within a column followed by the same letter are not significantly different based upon the adjustment for multiple comparisons using Bonferroni correction $\left(\alpha_{\mathrm{CER}}=0.005\right)$. 
had significant and negative correlations with SPAD at soft dough, hard dough, physiological maturity, and mean SPAD across the three developmental stages $(2013$, each at $P<0.0001 ; 2014, P<0.0001$, $0.0003,0.0012$, and 0.0001 , respectively). The difference between TSW per panicle ( $\Delta$ TSW) after control and pathogen inoculations was significantly and positively correlated to the difference between control and pathogen-treated plant SPAD $\left(\Delta \mathrm{SPAD}_{p m}\right)$ readings at physiological maturity (2013: $r=+0.47, P=0.008 ; 2014: r=+0.35$, $P=0.014) . \Delta \mathrm{SPAD}_{p m}$ explained 22 and $12 \%$ of the total observed variation in $\Delta$ TSW in 2013 and 2014, respectively (Fig. 2).

\section{Discussion}

Stalk rots cause significant global economic loss, and use of resistant cultivars is essential for managing these diseases (Tesso et al.

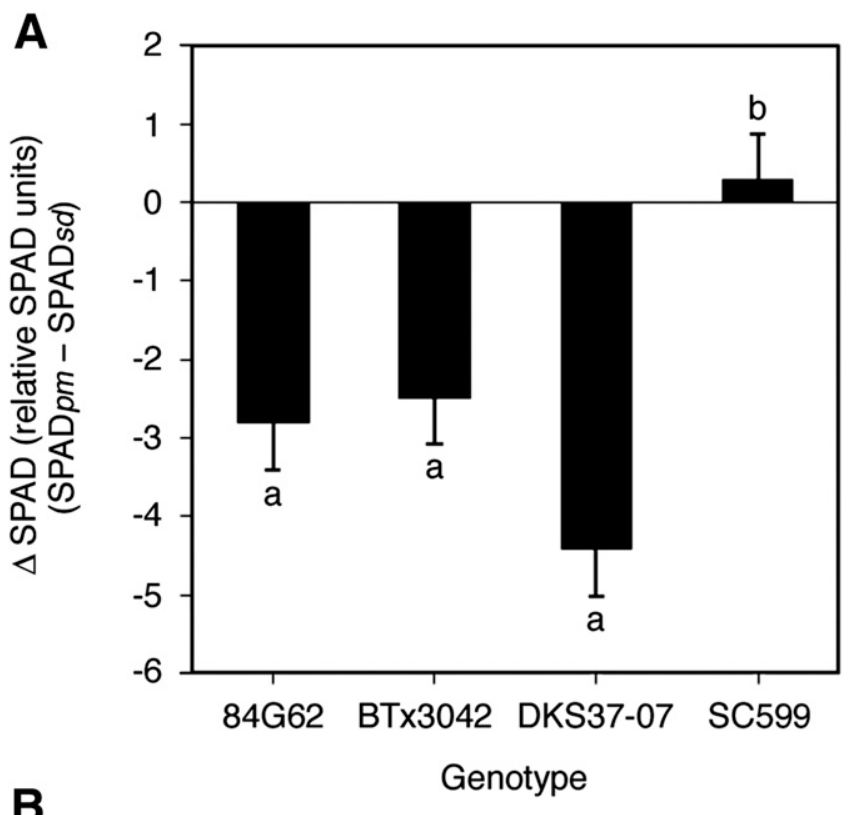

B

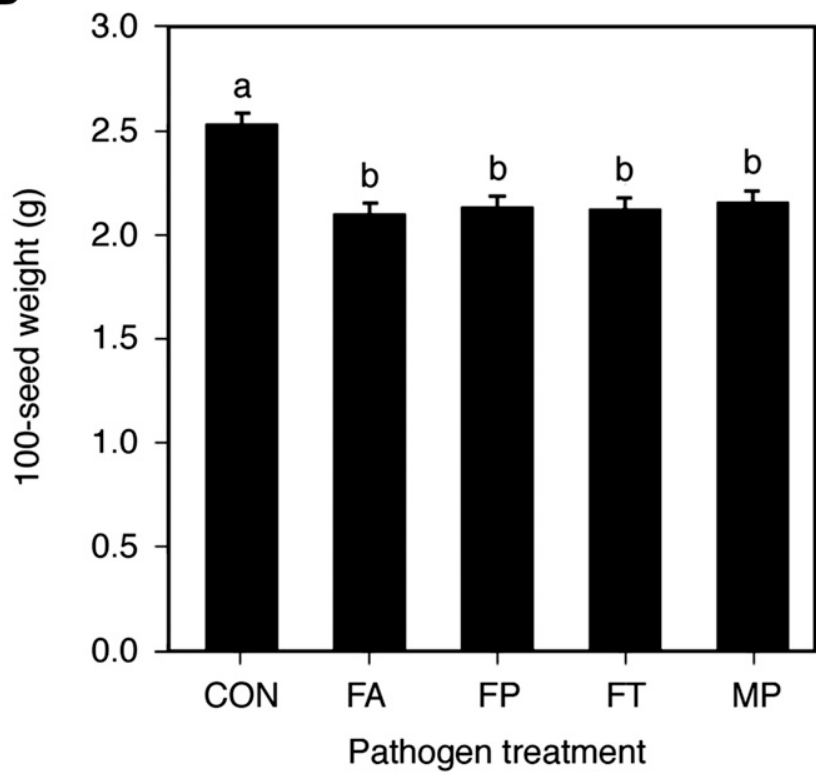

Fig. 1. A, Comparison of $\triangle S P A D$ (soil and plant analytical development [SPAD] meter reading difference between physiological maturity [SPAD $\left.D_{p m}\right]$ and soft dough stage $\left[\mathrm{SPAD}_{\text {sd }}\right] \pm$ standard error) of tested sorghum lines (SC599 and BTx3042) and hybrids (84G62 and DKS37-07) across five pathogen treatments and two environments. B, Effect of pathogens on 100-seed weight (in grams) across four genotypes and two experiments using Tukey-Kramer's test. Means followed by the same letters are not significantly different based on the adjusted $P$ value for multiple comparisons at $\alpha=0.05$. CON $=$ mock-inoculated control (phosphate-buffered saline), $\mathrm{FA}=$ Fusarium andiyazi, $\mathrm{FP}=F$. proliferatum, $\mathrm{FT}=F$. thapsinum, and $\mathrm{MP}=$ Macrophomina phaseolina
2012). Despite the absence of reported experimental evidence for the potential correlation between staygreen and stalk rot resistance, staygreen has been accepted as a means of physiological resistance. Most stalk-rot-resistant sorghum genotypes, including 'SC599', 'SC33', and 'SC35', possess the staygreen trait (Bramel-Cox et al. 1988; Woodfin et al. 1988). These reports suggest that indirect selection for staygreen can be used to identify genotypes with superior stalk rot resistance. Visual scoring of the staygreen trait is performed at or soon after physiological grain maturity. However, visual ratings could have some limitations, including disparities in rating scores among observers and individual biases (Rosenow 1994). Xu et al. (2000) showed that staygreen is highly correlated with chlorophyll content (as measured by a SPAD meter). Therefore, SPAD is a reliable and high-throughput method for assessing the staygreen trait. There are five types of staygreen based upon leaf senescence behavior (Thomas and Howarth 2000; Thomas and Smart 1993). The functional staygreen types A and B maintain both leaf greenness and photosynthetic activity much longer, while the nonfunctional staygreen types $\mathrm{C}, \mathrm{D}$, and $\mathrm{E}$ have persistent leaf greenness without sustaining photosynthetic competence during senescence. Therefore, type A and B sorghum genotypes, compared with other types, are most likely to provide some physiological resistance against stalk rot diseases.

The first objective was to investigate whether stalk rot pathogens affected leaf chlorophyll content. Results revealed the ability of stalk rot pathogens to reduce SPAD in a significant genotype- and developmental stage-specific manner. Currently, although the literature does not describe the potential involvement of stalk rot pathogens in altering sorghum chlorophyll metabolism, Kariola et al. (2005) demonstrated that chlorophyllase 1 (encoded by AtCLH1) of Arabidopsis thaliana was quickly induced after infection with the necrotrophic fungus Alternaria brassicicola, leading to enhanced chlorophyll degradation. It is possible that stalk rot pathogens also decrease chlorophyll biosynthesis while increasing chlorophyll degradation through upregulation of host genes that encode for enzymes such as chlorophyllase.

Our second objective was to test whether staygreen genotypes are more resilient to stalk-rot-mediated chlorophyll degradation. SC599 exhibited a higher SPAD at physiological maturity than at the soft dough stage across two environments and five treatments (Fig. 1). In contrast, the other three genotypes had lower SPAD readings at physiological maturity than at soft dough stage. Green-leaf-area duration during grain filling is a result of different combinations of green leaf area at flowering, senescence onset time, and rate of senescence (Borrell et al. 2000a; van Oosterom et al. 1996). SPAD difference between physiological maturity and soft dough stage (e.g., $\triangle$ SPAD) is indicative of the rate of senescence. It is clear that SC599 maintains a greater green-leaf-area duration during grain filling through a negative rate of senescence (i.e., SPAD increases over time from soft dough to physiological maturity), even in the presence of pathogens, whereas the other three genotypes exhibited a positive senescence rate. Consequently, it is apparent that SC599 belongs to

Table 3. Mean total seed weight per panicle (in grams) among sorghum genotypes after inoculation with phosphate-buffered saline (control), Fusarium andiyazi, F. proliferatum, $F$. thapsinum, and Macrophomina phaseolina across two environments ${ }^{\mathrm{z}}$

\begin{tabular}{lccccc}
\hline & \multicolumn{2}{c}{ Hybrids } & & \multicolumn{2}{c}{ Lines } \\
\cline { 2 - 3 } \cline { 5 - 6 } Treatment & $\mathbf{8 4 G 6 2}$ & DKS37-07 & & BTx3042 & SC599 \\
\hline Control & $93.6 \mathrm{a}$ & $82.1 \mathrm{a}$ & & 32.9 & $53.3 \mathrm{a}$ \\
F. andiyazi & $76.8 \mathrm{~b}$ & $53.9 \mathrm{~b}$ & & $19.5 \mathrm{~b}$ & $34.6 \mathrm{~b}$ \\
F. proliferatum & $69.3 \mathrm{~b}$ & $53.5 \mathrm{~b}$ & & $18.3 \mathrm{~b}$ & $27.8 \mathrm{~b}$ \\
F. thapsinum & $60.2 \mathrm{~b}$ & $40.3 \mathrm{~b}$ & & $19.3 \mathrm{~b}$ & $36.2 \mathrm{~b}$ \\
M. phaseolina & $61.7 \mathrm{~b}$ & $42.4 \mathrm{~b}$ & & $16.8 \mathrm{~b}$ & $33.0 \mathrm{~b}$ \\
\hline
\end{tabular}

${ }^{\mathrm{z}}$ Means within a column followed by the same letter are not significantly different based upon the adjustment for multiple comparisons using Bonferroni correction $\left(\alpha_{\text {CER }}=0.005\right)$. Standard error: \pm 4.6 for hybrids and \pm 2.8 for lines. 
the functional staygreen category and exhibits the characteristics of both A and B staygreen types. Type A staygreen shows delayed senescence compared with wild-type plants yet has the same rate of chlorophyll degradation as in the wild type after senescence begins, whereas type B initiates senescence at the same time but exhibits a much slower decrease of chlorophyll content and photosynthetic activity (Thomas and Howarth 2000; Thomas and Smart 1993). Interestingly, the hybrid DKS37-07, designated as staygreen by the seed company, did not show the same phenomenon. Although the plants that were inoculated with PBS showed constant SPAD through physiological maturity, it exhibited the highest SPAD reduction from soft dough to physiological maturity across pathogen treatments (Fig. 1). This is possibly attributed to the greater chlorophyll catabolism (enhanced chlorophyllase production) and lower anabolism of DKS37-07 under stalk rot pathogen infection at physiological maturity compared with those of SC599 and N remobilization pattern differences among functional and nonfunctional staygreen types.

In functional staygreen genotypes, the $\mathrm{C}-\mathrm{N}$ transition point is delayed, or the transition occurs on time but subsequent yellowing and $\mathrm{N}$ remobilization occur slowly (Thomas and Howarth 2000; Yoo et al. 2007). However, delaying the $\mathrm{C}-\mathrm{N}$ transition and slowing foliar senescence may compromise yield, particularly in high-N genotypes. Evidence in the literature suggests that the functional staygreen trait can be of limited or even negative value, particularly in oilseed crops such as soybean (Kumudini 2002) and legumes such as cowpea (Ismail et al. 2000). Using five high-yielding sorghum hybrids, Youngquist and Maranville (1992) demonstrated that stem and leaf fractions lost from 45 to $69 \%$ of their $\mathrm{N}$ content during grain filling. They also found 44 to $57 \%$ of plant $\mathrm{N}$ in the stem and 43 to $56 \%$ in the leaves at anthesis. However, at maturity, 58 to $68 \%$ of total plant $\mathrm{N}$ was in the grain, while 14 to $17 \%$ remained in the stems and 18 to $25 \%$ in the leaves. Therefore, with the high demand for $\mathrm{N}$ remobilization toward the sorghum panicle, high-yielding hybrids such as DKS37-07 may be unable to maintain higher chlorophyll contents in leaves during later stages of their life cycle, particularly when soil N content is limited. Therefore, DKS37-07 may belong to the nonfunctional staygreen category, representing type $\mathrm{C}$ or $\mathrm{E}$. Type $\mathrm{C}$ retains chlorophyll almost indefinitely in the senescent leaves, although their photosynthetic capacity typically decreases during senescence, while type E maintains a much higher chlorophyll level throughout leaf development without increasing photosynthetic competence (Thomas and Howarth 2000; Thomas and Smart 1993).

Significant pathogen-genotype-environment interactions observed for lesion length elucidated the genotype- and environment-dependent aggressiveness of stalk rot pathogens. There were no significant differences among pathogens on SC599 for either year, demonstrating SC599's similar levels of resistance against tested pathogens. Although BTx3042 is known to be highly susceptible to Fusarium stalk rot, it showed the shortest lesion length against the $F$. thapsinum isolate used for these inoculations in both environments. $F$. thapsinum is widely recognized as the most aggressive Fusarium sp. causing stalk rot (Leslie et al. 2005; Tesso and Ejeta 2011; Tesso et al. 2005, 2010) (Table 4). Fusarium stalk rot is usually more severe when drought and heat stresses occur during grain development followed by wet and cool conditions near physiological maturity (Tesso et al. 2012). BTx3042 attained physiological maturity in October under both environments. Although a considerable amount of rain was received during the month of October $(2013,98.3 \mathrm{~mm} ; 2014,90.2 \mathrm{~mm}$; 30 -year average, $65.3 \mathrm{~mm}$ ), contributing to wet conditions, the monthly mean temperature in October was $23.3^{\circ} \mathrm{C}$ under both environments (30-year average, $13.5^{\circ} \mathrm{C}$ ). It is possible that much cooler conditions are required by $F$. thapsinum to cause more disease in BTx3042 compared with the other genotypes tested. However, M. phaseolina produced the longest lesion length on BTx3042 in both environments. Because $M$. phaseolina is a necrotrophic pathogen and takes advantage of senescing tissues for rapid growth, delayed senescence may provide some protection against the pathogen. Compared with other sorghum genotypes tested in this study, SC599 showed lower lesion lengths against $M$. phaseolina under both environments. As mentioned above, SC599 is capable of maintaining a negative senescence rate from soft dough to physiological maturity. Hence, it can be considered to be a genotype showing strong delayed senescence which, in turn, may contribute to enhanced resistance against M. phaseolina.

Compared with the sorghum lines, both hybrids tested in this study showed longer lesion lengths when inoculated with $F$. thapsinum under both environments. This finding supports the idea that highyielding genotypes are more vulnerable to Fusarium stalk rot, which

Table 4. Mean lesion lengths \pm standard error (in centimeters) among sorghum genotypes after inoculation (Inoc) with phosphate-buffered saline (control [Con]), Fusarium andiyazi (FA), F. proliferatum (FP), F. thapsinum (FT), and Macrophomina phaseolina (MP) in 2013 and $2014^{z}$

\begin{tabular}{|c|c|c|c|c|c|c|c|c|}
\hline \multirow[b]{3}{*}{ Inoc } & \multicolumn{8}{|c|}{ Genotype } \\
\hline & \multicolumn{2}{|c|}{$84 G 62$} & \multicolumn{2}{|c|}{ DKS37-07 } & \multicolumn{2}{|c|}{ BTX3042 } & \multicolumn{2}{|c|}{ SC599 } \\
\hline & 2013 & 2014 & 2013 & 2014 & 2013 & 2014 & 2013 & 2014 \\
\hline Con & $0.5 \mathrm{a} \pm 0.1$ & $0.5 \mathrm{a} \pm 1.0$ & $0.8 \mathrm{a} \pm 0.1$ & $0.5 \mathrm{a} \pm 1.0$ & $0.5 \mathrm{a} \pm 0.1$ & $0.7 \mathrm{a} \pm 1.0$ & $0.5 \mathrm{a} \pm 0.1$ & $0.6 \mathrm{a} \pm 1.0$ \\
\hline FA & $4.2 \mathrm{bd} \pm 1.1$ & $6.3 b c \pm 1.0$ & $8.0 b c \pm 1.1$ & $7.4 \mathrm{~b} \pm 1.0$ & $6.0 \mathrm{bc} \pm 1.1$ & $5.3 \mathrm{~b} \pm 1.0$ & $3.7 \mathrm{~b} \pm 1.1$ & $3.0 \mathrm{~b} \pm 1.0$ \\
\hline FP & $6.8 \mathrm{~d} \pm 0.6$ & $9.3 \mathrm{c} \pm 1.0$ & $6.5 c \pm 0.6$ & $7.1 \mathrm{~b} \pm 1.0$ & $7.5 \mathrm{~b} \pm 0.6$ & $7.1 \mathrm{~b} \pm 1.0$ & $3.0 \mathrm{~b} \pm 0.6$ & $4.4 \mathrm{~b} \pm 1.0$ \\
\hline FT & $11.2 \mathrm{c} \pm 0.7$ & $7.5 b c \pm 1.0$ & $9.7 b \pm 0.7$ & $7.6 \mathrm{~b} \pm 1.0$ & $3.8 \mathrm{c} \pm 0.7$ & $4.0 \mathrm{~b} \pm 1.0$ & $3.7 b \pm 0.7$ & $5.8 \mathrm{~b} \pm 1.0$ \\
\hline MP & $4.0 \mathrm{~b} \pm 0.4$ & $4.7 \mathrm{~b} \pm 1.0$ & $5.7 \mathrm{c} \pm 0.4$ & $5.8 \mathrm{~b} \pm 1.0$ & $8.8 \mathrm{~b} \pm 0.4$ & $7.2 b \pm 1.0$ & $3.8 \mathrm{~b} \pm 0.4$ & $3.0 \mathrm{~b} \pm 1.0$ \\
\hline
\end{tabular}

${ }^{\mathrm{z}}$ Means within a column followed by the same letter are not significantly different based upon the adjustment for multiple comparisons using Bonferroni correction $\left(\alpha_{\mathrm{CER}}=0.005\right)$.

Table 5. Pearson correlation coefficients and significance levels among yield, severity, and soil and plant analytical development (SPAD) traits for four genotypes after inoculation with F. thapsinum, F. andiyazi, F. proliferatum and M. phaseolina in 2013 (top, right, environment 1) and 2014 (bottom, left, environment 2) $(\alpha=0.05)^{\mathrm{z}}$

\begin{tabular}{|c|c|c|c|c|c|c|c|}
\hline & TSW & HSW & $\mathbf{L L}$ & SPAD & SD & HD & PM \\
\hline TSW & 1 & $0.73 * * *$ & $-0.21 *$ & $0.59 * * *$ & $0.50 * * *$ & $0.53 * * *$ & $0.62 * * *$ \\
\hline SW & $0.64 * * *$ & 1 & -0.12 & $0.33^{*}$ & $0.31^{*}$ & $0.31^{*}$ & $0.49 * * *$ \\
\hline LL & $-0.20 *$ & -0.11 & 1 & $-0.58 * * *$ & $-0.49 * * *$ & $-0.57 * * *$ & $-0.54 * * *$ \\
\hline SPAD & $0.61 * * *$ & $0.64 * * *$ & $-0.49 * * *$ & 1 & $0.89 * * *$ & $0.96 * * *$ & $0.88 * * *$ \\
\hline SD & $0.50 * * *$ & $0.57 * * *$ & $-0.48 * * *$ & $0.93^{* * * *}$ & 1 & $0.82 * * *$ & $0.71 * * *$ \\
\hline HD & $0.61 * * *$ & $0.63 * * *$ & $-0.45^{* *}$ & $0.96^{* * * *}$ & $0.891 * * *$ & 1 & $0.87 * * *$ \\
\hline PM & $0.62 * * *$ & $0.61 * * *$ & $-0.41 * *$ & $0.94 * * *$ & $0.79 * * *$ & $0.87 * * *$ & 1 \\
\hline
\end{tabular}

${ }^{\mathrm{z}} \mathrm{TSW}=$ total seed weight per panicle (in grams); HSW = 100-seed weight (in grams); LL = lesion length (in centimeters); SPAD = mean SPAD across soft dough (SD), hard dough (HD), and physiological maturity (PM); *,**, and *** indicate $P<0.05,0.001$, and 0.0001 , respectively. 
is in agreement with Seetharama et al. (1991). These authors hypothesized that stalk rot is more severe in cultivars that utilize stem carbohydrates for higher yield compared with genotypes that exhibit lower grain yield because they do not mobilize stem carbohydrates. Furthermore, Clark and Miller (1980) showed that stalk sugar content is positively correlated with stalk rot resistance.

The present study provided evidence that the staygreen trait is correlated with decreased disease severity and, thus, increased plant resistance to stalk rot diseases. Because the difference between control and pathogen-treated TSW per panicle ( $\Delta \mathrm{TSW}$, indicative of host tolerance) was significantly and positively correlated with the difference between control and pathogen-treated SPAD at physiological maturity $\left(\Delta \mathrm{SPAD}_{p m}\right)$, the potential involvement of staygreen in enhancing the plant's tolerance to stalk rot diseases was evident. Although regression analysis did not reveal much stronger $R^{2}$ values for models fitted between $\Delta \mathrm{TSW}$ (the response variable) and $\Delta \mathrm{SPAD}_{p m}$ (the explanatory variable) under both environments, they were still statistically significant (Fig. 2). Moderate $R^{2}$ values were not surprising because only one explanatory variable $\left(\Delta \mathrm{SPAD}_{p m}\right)$ was incorporated into the models.

The results of this study demonstrated the ability of stalk rot pathogens to reduce SPAD in a significant genotype- and developmental stage-specific manner. A commonly used stalk-rot-resistant and staygreen check line, SC599, showed a remarkable feature of negative senescence rate from soft dough to physiological maturity under disease pressure (also under no disease pressure). This phenomenon may be the best manifestation of the staygreen trait that contributes to enhanced stalk rot resistance. Results also indicated that staygreen is strongly and positively correlated with disease resistance and tolerance. Therefore, using grain sorghum as a model plant, we provide evidence of the potential involvement of the staygreen trait in enhancing sorghum stalk rot resistance and tolerance. The staygreen

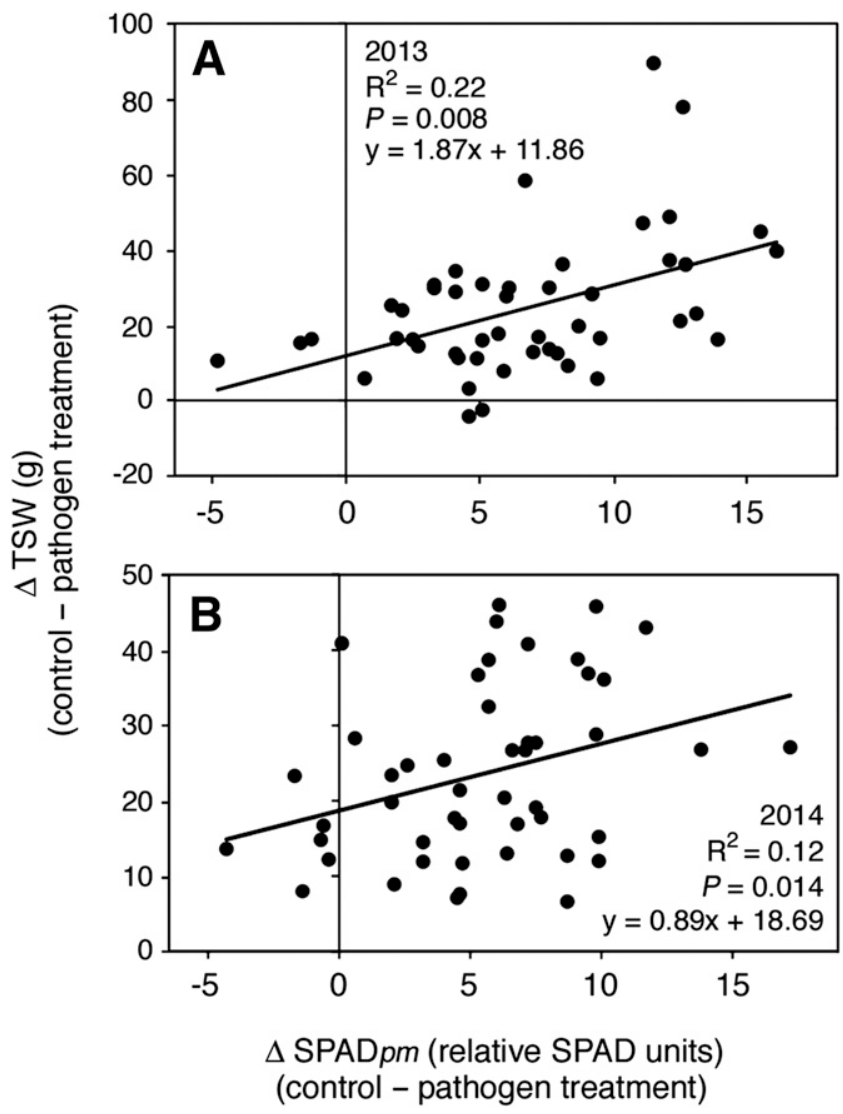

Fig. 2. Scatter plots showing the relationship of $\triangle S P A D_{p m}$ (in relative soil and plant analytical development [SPAD] units) at physiological maturity (mock-inoculated control - pathogen treatment) with total seed weight per panicle ( $\Delta T S W$; mockinoculated control - pathogen treatment) in the A, 2013 and B, 2014 experiments. trait deserves continued consideration in breeding efforts that particularly focus on producing hybrids that yield better under predicted, intensified future drought conditions and associated stalk rot incidence. It is also possible that staygreen is instrumental in reducing yield losses associated with various foliar diseases caused by numerous pathogens, including bacteria, fungi, and viruses, for many economically important crops. Given its various physiological resistance benefits, staygreen should remain a central trait to be pursued in sorghum given the climatic changes, increased disease occurrence, rapid population growth, and threatened food security predicted for our future.

\section{Acknowledgments}

We thank the Kansas Grain Sorghum Commission for their financial support of this research.

\section{Literature Cited}

Araus, J. L., Slafer, G. A., Reynolds, M. P., and Royo, C. 2002. Plant breeding and water relations in C3 cereals: What should we breed for? Ann. Bot. (Lond.) 89 925-940.

Bandara, Y. M. A. Y., Perumal, R., and Little, C. R. 2015. Integrating resistance and tolerance for improved evaluation of sorghum lines against Fusarium stalk rot and charcoal rot. Phytoparasitica 43:485-499.

Borrell, A. K., Hammer, G. L., and Douglas, A. C. L. 2000a. Does maintaining green leaf area in sorghum improve yield under drought? I. Leaf growth and senescence. Crop Sci. 40:1026-1037.

Borrell, A. K., Hammer, G. L., and Henzell, R. G. 2000b. Does maintaining green leaf area in sorghum improve yield under drought? II. Dry matter production and yield. Crop Sci. 40:1037-1048

Bramel-Cox, P. J., Stein, I. S., Rodgers, D. M., and Claflin, L. E. 1988. Inheritance of resistance to Macrophomina phaseolina (Tassi) Goid and Fusarium monliforme Sheldon in sorghum. Crop Sci. 28:37-40.

Clark, J. W., and Miller, F. R. 1980. Relationship of stalk sweetness and stalk rot disease. Sorghum Newsl. 23:131.

Dodd, J. L. 1980. The photosynthetic stress translocation balance concept of sorghum stalk rot. Pages 300-305 in: Proc. Int. Workshop Sorghum Dis. Texas A\&M University. ICRISAT Press, Hyderabad, India.

Gray, F. A., Mihail, J. D., Lavigne, R. J., and Porter, P. M. 1991. Incidence of charcoal rot of sorghum and soil populations of Macrophomina phaseolina associated with sorghum and native vegetation in Somalia. Mycopathologia 114:145-151.

Hundekar, A. R., and Anahosur, K. H. 1994. Pathogenicity of fungi associated with sorghum stalk rot. Karnataka J. Agric. Sci. 7:291-295.

IPCC. 2007. Intergovernmental Panel on Climate Change (IPCC) Fourth Assessment Report. Climate Change. Cambridge University Press, Cambridge, UK.

Ismail, A. M., Hall, A. E., and Ehlers, J. D. 2000. Delayed leaf senescence and heat tolerance traits mainly are independently expressed in cowpea. Crop Sci. 40 1049-1055.

Jardine, D. J., and Leslie, J. F. 1992. Aggressiveness of Gibberella fujikuroi (Fusarium monliforme) isolates to grain sorghum under greenhouse conditions. Plant Dis. 76:897-900.

Kariola, T., Brader, G., Li, J., and Palva, E. T. 2005. Chlorophyllase 1, a damage control enzyme, affects the balance between defense pathways in plants. Plant Cell 17:282-294.

Kumudini, S. 2002. Trials and tribulations: A review of the role of assimilate supply in soybean genetic yield improvement. Field Crops Res. 75:211222.

Leslie, J. F., Zeller, K. A., Lamprecht, S. C., Rheeder, J. P., and Marasas, F. O. 2005. Toxicity, pathogenicity and genetic differentiation of five species of Fusarium from sorghum and millet. Phytopathology 95:275-283.

Meehl, G. A., Arblaster, J. M., and Tebaldi, C. 2007. Contribution of natural and anthropogenic forcing to changes in temperature extremes over the United States. Geophys. Res. Lett. 34:L19709.

Mughogho, L. K., and Pande, S. 1984. Charcoal rot of sorghum. Pages 11-24 in: Sorghum Root and Stalk Rots, a Critical Review. Proc. Consult. Group Discuss. Res. Needs Strategies Control Root Stalk Rot Dis. Bellagio, Italy. G. Rosenberg, eds. ICRISAT Press, Patancheru, India.

Rosenow, D. T. 1994. Evaluation for drought and disease resistance in sorghum for use in molecular marker-assisted selection. Pages 27-31 in: Proc. Use Mol. Markers Sorghum Pearl Millet Breed. Dev. Countries. J. R. Witcombe and R. R. Duncan, eds. Overseas Development Administration, Norwich, U.K.

Rosenow, D. T., Johnson, J. W., Fredriksen, R. A., and Miller, F. R. 1977. Relationship of non-senescence to lodging and charcoal rot in Sorghum roo and stalk rots. Page 69 in: Agronomy Abstracts. American Society of Agronomy, Madison, WI.

SAS Institute. 2008. The SAS Users Guide, Version 9.2. SAS Institute, Cary, NC Seetharama, N., Bidinger, F. R., Rao, K. N., Gill, K. S., and Mulgund, M. 1987. Effect of pattern and severity of moisture deficit stress on stalk rot incidence in sorghum. I. Use of line source irrigation technique, and the effect of time of inoculation. Field Crops Res. 15:289-308. 
Seetharama, N., Sachan, R. C., Huda, A. K., Gill, K. S., Rao, K. N., and Bidinger, F. R. 1991. Effect of pattern and severity of moisture deficit stress on stalk rot incidence in sorghum. II. Effect of source/sink relationships. Field Crops Res. 26:355-374.

Smith, G. S., and Wyllie, T. D. 1999. Charcoal rot. Pages 29-31 in: Compendium of Soybean Disease, 4th ed. G. L. Hartman, J. B. Sinclair, and J. C. Rupe, eds. American Phytopathological Society, St. Paul, MN.

Tarr, S. A. J. 1982. Diseases of Sorghum, Sudan Grass, and Brown Corn. Commonwealth Mycological Institute, Kew, Surrey, U.K.

Tenkouano, A., Miller, E. R., Frederiksen, R. A., and Rosenow, D. T. 1993. Genetics of nonsenescence and charcoal rot resistance in sorghum. Theor. Appl. Genet. 85:644-648.

Tesso, T., Claflin, L. E., and Tuinstra, M. R. 2004. Estimation of combining ability for resistance to Fusarium stalk rot in grain sorghum. Crop Sci. 44:1195-1199.

Tesso, T., and Ejeta, G. 2011. Stalk strength and reaction to infection by Macrophomina phaseolina of brown midrib maize (Zea mays) and sorghum (Sorghum bicolor). Field Crops Res. 120:271-275.

Tesso, T., Perumal, R., Little, C. R., Adeyanju, A., Radwan, G. L., Prom, L. K., and Magill, C. W. 2012. Sorghum pathology and biotechnology-A fungal disease perspective: Part II. Anthracnose, stalk rot, and downy mildew. Eur. J. Plant Sci. Biotechnol. 6:31-44.

Tesso, T. T., Claflin, L. E., and Tuinstra, M. R. 2005. Analysis of stalk rot resistance and genetic diversity among drought tolerant sorghum genotypes. Crop Sci. 45:645-652.

Tesso, T. T., Ochanda, N., Little, C. R., Claflin, L., and Tuinstra, M. R. 2010. Analysis of host plant resistance to multiple Fusarium species associated with stalk rot disease in sorghum [Sorghum bicolor (L.) Moench]. Field Crops Res. 118:177-182.

Thomas, H., and Howarth, C. J. 2000. Five ways to stay green. J. Exp. Bot. 51: 329-337.

Thomas, H., and Smart, C. M. 1993. Crops that stay green. Ann. Appl. Biol. 123: 193-219.

Uddling, J., Gelang-Alfredsson, J., Piikki, K., and Pleijel, H. 2007. Evaluating the relationship between leaf chlorophyll concentration and SPAD-502 chlorophyll meter readings. Photosynth. Res. 91:37-46.

van Oosterom, E. J., Jayachandran, R., and Bidinger, F. R. 1996. Diallel analysis of the stay-green trait and its components in sorghum. Crop Sci. 36:549-555.

Woodfin, C. A., Rosenow, D. T., and Clark, L. E. 1988. Association between the stay green trait and lodging resistance in sorghum. Page 102 in: Agronomy Abstracts. American Society of Agronomy, Madison, WI.

$\mathrm{Xu}$, W., Rosenow, D. T., and Nguyen, H. T. 2000. Stay green trait in grain sorghum: Relationship between visual rating and leaf chlorophyll concentration. Plant Breed. 119:365-367.

Yamamoto, A., Nakamura, T., Adu-Gyamfi, J. J., and Saigusa, M. 2002. Relationship between chlorophyll content in leaves of sorghum and pigeonpea determined by extraction method and by chlorophyll meter (SPAD-502). J. Plant Nutr. 25:2295-2301.

Yoo, S., Cho, S., Zhang, H., Paik, H., Lee, C., Li, J., Yoo, J., Lee, B., Koh, H., Seo, H., and Paek, N. C. 2007. Quantitative trait loci associated with functional staygreen SNU-SG1 in rice. Mol. Cells 24:83-94.

Youngquist, J. B., and Maranville, J. W. 1992. Patterns of nitrogen mobilization in grain sorghum hybrids and the relationship to grain and dry matter production. J. Plant Nutr. 15:445-455 